Portland State University

PDXScholar

7-31-2018

\title{
Variability in Volcanic Glass Preparation Methods: Qualitative Analysis of Apparent Porosity between Pumiceous and Non-Pumiceous Glass Shards
}

Zach Nuhring

Portland State University

Follow this and additional works at: https://pdxscholar.library.pdx.edu/honorstheses Let us know how access to this document benefits you.

\section{Recommended Citation}

Nuhring, Zach, "Variability in Volcanic Glass Preparation Methods: Qualitative Analysis of Apparent Porosity between Pumiceous and Non-Pumiceous Glass Shards" (2018). University Honors Theses. Paper 632.

https://doi.org/10.15760/honors.647

This Thesis is brought to you for free and open access. It has been accepted for inclusion in University Honors Theses by an authorized administrator of PDXScholar. Please contact us if we can make this document more accessible: pdxscholar@pdx.edu. 
Variability in Volcanic Glass Preparation Methods: Qualitative Analysis of Apparent Porosity between Pumiceous and Non-Pumiceous Glass Shards

By Zach Nuhring

An undergraduate honors thesis submitted in partial fulfillment of the requirements for the degree of

Bachelor of Science

in

University Honors

and

Geology

Advisers:

John Bershaw

and

Tessa Carlson

Portland State University

2018 


\begin{abstract}
Stable isotopes from ancient water have been used extensively to reconstruct paleoclimates and paleoenvironments (e.g. Bershaw et al., 2010, Cyr et al., 2005, Fan et al., 2017, Quade et al., 2011, Rowley and Garzione, 2007). Volcanic glass found in ash tuffs have been shown to preserve hydrogen $(\mathrm{H})$ isotopes from meteoric water at the time of deposition (Cassel and Breecker, 2017) making it a useful paleowater proxy (e.g. Canavan et al., 2014, Cassel et al., B2009, Friedman et al., 2013, Saylor and Horton, 2014). Carlson (2018) showed differences in $\delta \mathrm{D}$ between two different preparation methods in volcanic glass analysis and suggests that strict grain size filtering and hydrofluoric acid (HF) treatment produce the most reliable results, similar to Cassel and Breecker (2017) findings. Samples were deemed reliable if they contained $>99 \%$ glass without bubbles. Glass shards with bubbles are less dense and described as pumiceous. Though preparation methods recommend removing pumiceous shards, it is not clear how they affect isotopic results, if at all. I investigate this by comparing pumiceous textures, water concentration, and $\delta \mathrm{D}$ values of different glass samples. Based on the results of this pilot I conclude that; 1) $\delta \mathrm{D}$ and wt. \% water are not affected by apparent porosity, 2) The Cassel and Breecker (2017) method effectively removes hydrogen contamination, even in previously discarded pumiceous samples where corrosion is extensive, suggesting pumiceous glass shards can also be used for paleoenvironmental reconstruction. Future work should confirm these results with a more extensive dataset.

\section{Background}

Deuterium (D) is the heavy stable isotope of hydrogen. Isotopic ratios of hydrogen $(\mathrm{H})$ to Deuterium are utilized in this study. Deuterium values $(\delta \mathrm{D})$ are expressed as parts per thousand $(\%)$ deviations from a standard. $\delta \mathrm{D}$ values of meteoric water evolve throughout the hydrologic cycle and are affected significantly by elevation and climate. By analyzing paleowater preserved in proxy material from the rock record, including tuff, researchers are able to reconstruct paleoenvironments.

Volcanic glass varies widely in its permeability, porosity (vesicularity), and surface area to volume ratio. As magma ascends from deep in the Earth, the pressure-dependent solubility of water causes bubbles to form from volatiles exsolving (Fisher and Schmincke, 1984). In addition, bubbles form during the cooling of magma (Williams and McBirney, 1979). After formation, volcanic glass has between 0.1 - 0.5 wt.\% magmatic water (Grunder et al., 2015). Over the following $10^{4}$ years, the glass gains up to $10 \mathrm{wt}$. \% water derived from its environment (Cerling et al., 1985; Giachetti et al., 2015; Parruzot et al., 2015). Following hydration, Nolan and Bindeman (2013) concluded that $\delta \mathrm{D}$ in silt sized $(<70 \mu \mathrm{m})$ glass shards can continue to change over a short time frame when exposed to highly enriched water ( $\delta \mathrm{D}$ values up to 18,205\%o). However, Cassel and Breecker (2017) suggest that post-hydration corrosion and alteration is limited to the surface which can be effectively removed with HF acid treatment in 70 $-150 \mu \mathrm{m}$ size shards.

Samples from three unique formations are analyzed in this study (Table 1). Sample CVG027 is from the Deschutes Formation, dated between 5.99 and 5.67 Ma. It is a non-welded, fine-grained tuff interpreted to be a fluvially reworked ash-fall deposit (Pitcher et al., 2017). The second, CVG029 is a Quaternary-aged non-welded tuff that overlies a basalt flow and the only ash interpreted to be reworked by aeolian processes. It is dated between $0.055-0.007 \mathrm{Ma}$ 
(Peterson and Groh, 1970). The third, CVG034 is from the Mascall Formation, dated at 17.6-14 Ma. It is a non-welded fine-grained tuff interpreted to be a fluvially reworked ash-fall deposit (Bestland et al., 2008, Fiebelkorn et al., 1983). Samples are taken in bulk to be processed for $\delta D$ analysis. All of the samples within each formation were collected at the same outcrop.

To remove impurities in glass samples used for paleoenvironmental reconstruction, many sample prep methods have been used. Two popular examples are described by Cassel and Breecker (2017) and Seligman et al. (2016). Carlson (2018) concluded that the Cassel and Breecker (2017) method produced the most reliable results for paleoenvironmental analysis. Seligman et al. (2016) uses sonicating and rinsing of samples with hydrochloric acid ( $\mathrm{HCl}$ ) and selects samples by hand selection (Carlson, 2018). The Cassel and Breecker (2017) method starts by crushing, sieving, and drying the tuff samples. To remove surface impurities from the glass, all samples are washed twice in $10 \% \mathrm{HCl}$ for 30 seconds and twice in $8 \% \mathrm{HF}$ for 30 seconds. Magnetic minerals are removed with repeated passes through a Frantz Isodynamic Separator. In addition, the heavy liquid lithium metatungstate (LMT) is used to create a density gradient of ash constituents. Figure 1 shows the difference between medium density samples and low-density pumiceous samples separated using LMT. On the right are glass shards that contain bubbles, identified as black circles, and on the left is a sample without. Pumiceous shards have a higher surface area per unit volume ratio and so are more likely to have secondary minerals within crevices and surface alteration that may not be fully removed by pre-treatments (Cassel and Breecker, 2017). Figure 2 shows an example of LMT density separation with different layers created. Relatively low density pumiceous glass floats to the top of a funnel and heavier material, containing mineral contaminants, sinks to the bottom. All the pumiceous shards were collected from the A section and glass shards $>99 \%$ pure were taken from B and used in Carlson (2018).
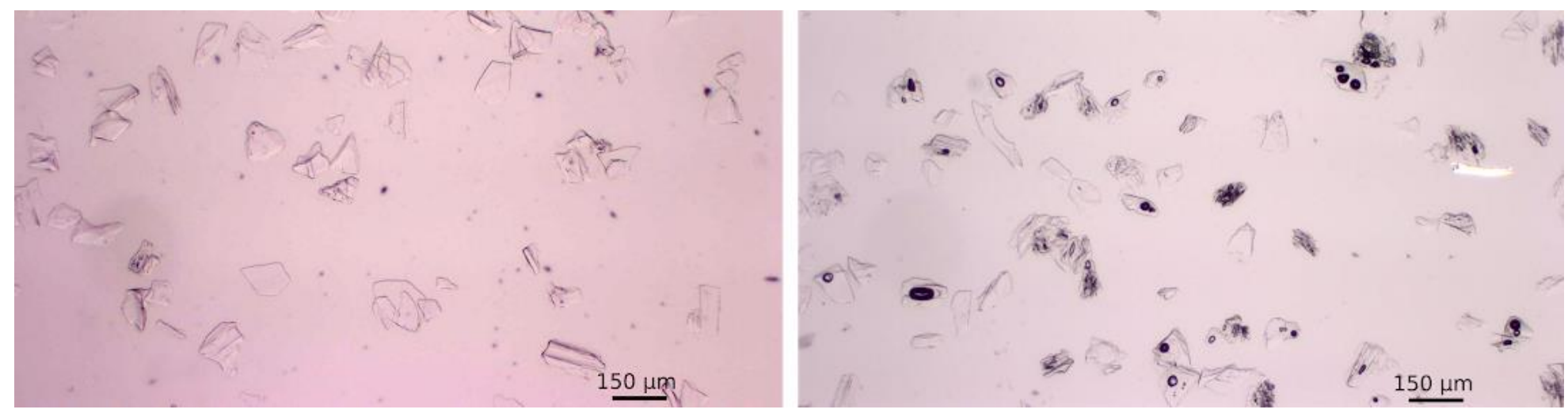

Figure 1 Sample 034. Images taken from Carlson 2018. Left is non-pumiceous, right is pumiceous. Photo by Tessa Carlson

\section{Hypothesis}

Pumiceous samples from the same outcrop as samples without a pumiceous texture will show a significant difference in $\delta \mathrm{D}$ values and water content (weight percent water or wt. $\%$ water) suggesting sample porosity is an important consideration when selecting tuff samples for paleoenvironmental reconstruction. 


\section{Methods}

Each formation has four $\delta \mathrm{D}$ values, two for pumiceous and two for non-pumiceous samples. Non-pumiceous sample results are from Carlson (2018). Pumiceous sample $\delta D$ results are from previously unpublished. Table 1 contains meta-data related to each individual rock sample, all prepared using the Cassel and Breecker (2017) method.

\begin{tabular}{|c|c|c|c|c|c|c|c|c|c|}
\hline Name/Formation & ID & Age (MA) & Lat & Long & Welding & Field Notes & Type & $\begin{array}{l}\text { Hydration } \\
\text { Water }\end{array}$ & $\begin{array}{l}\text { Age/Location } \\
\text { Reference }\end{array}$ \\
\hline Quaternary Ash & M2-CVG029 & 0.0550 .007 & 44.54448 & -121.25829 & Nonwelded & $\begin{array}{l}\text { Massive, friable, } \\
\text { light beige, overlies } \\
\sim 50 \text { Ka intra-canyon } \\
\text { basalt flow }\end{array}$ & $\begin{array}{l}\text { Aeolian } \\
\text { reworked } \\
\text { ash }\end{array}$ & Precipitation & $\begin{array}{l}\text { Peterson and } \\
\text { Groh, } 1970\end{array}$ \\
\hline $\begin{array}{l}\text { Mascall } \\
\text { Formation }\end{array}$ & M2-CVG034 & $17.6-14 a$ & 44.49972 & -119.62528 & Nonwelded & $\begin{array}{l}\text { 1-3m beds, fine } \\
\text { grained ash, crystal } \\
\text { poor, beige }(034)\end{array}$ & $\begin{array}{l}\text { Fluvially } \\
\text { reworked } \\
\text { ash-fall }\end{array}$ & $\begin{array}{l}\text { Fluvial, } \\
\text { Precipitation }\end{array}$ & $\begin{array}{l}\text { Bestland et al., } \\
2008, \\
\text { Fiebelkorn et } \\
\text { al., } 1983\end{array}$ \\
\hline $\begin{array}{l}\text { Deschutes } \\
\text { Formation }\end{array}$ & M2-CVG027 & 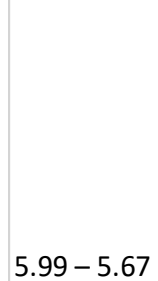 & 44.58083 & -121.42503 & Nonwelded & $\begin{array}{l}\text { Massive, beige, fine- } \\
\text { grained, crystal- } \\
\text { poor ash within } \\
\text { crossbedded } \\
\text { tuffaceous } \\
\text { sediments above } \\
\text { and below }\end{array}$ & $\begin{array}{l}\text { Fluvially } \\
\text { reworked } \\
\text { ash-fall }\end{array}$ & $\begin{array}{l}\text { Fluvial, } \\
\text { Precipitation }\end{array}$ & $\begin{array}{l}\text { Pitcher et al., } \\
2017\end{array}$ \\
\hline
\end{tabular}

Table 1: Sample age, location, and source information. Table adapted from Carlson (2018)

To more precisely characterize how pumiceous samples are, photos of sample thin sections were taken under a petrographic microscope. Each image was analyzed with ImageJ, a photo editing software, to characterize specific areas: total area of the image $\left(A_{i}\right)$, area of void space between shards $\left(A_{v}\right)$, area of the glass shards $\left(A_{g}\right)$, area of bubbles of the entire image $\left(\mathrm{A}_{\mathrm{bi}}\right)$, and area of bubbles of the glass shards $\left(\mathrm{A}_{\mathrm{bg}}\right)$. Based on these data, an apparent porosity $\left(\theta_{\mathrm{a}}\right)$ was calculated with the following equation:

$$
\theta_{a}=\frac{A_{b g}}{A_{g}}
$$

$A_{i}$ in pixels was calculated in Image $J$ by using the measure tool. To estimate $A_{v}$, the wand tool was first used to isolate the area of void space in pixels. Clicking with the wand in the void space of the image highlights all pixels of the same color. I continued to click around the glass shards until all the void space was highlighted. Again, the measure tool was used to calculate the area. By subtracting $\mathrm{A}_{\mathrm{v}}$ from $\mathrm{A}_{\mathrm{i}}, \mathrm{A}_{\mathrm{g}}$ was estimated. To measure the area of the bubbles, the black in the images was turned red using the color threshold tool. The measure tool again was used to estimate the red in the image to obtain $\%$ area of bubbles within the entire image $\left(\mathrm{A}_{\mathrm{bi}}\right)$. Figure 3 shows an example of using ImageJ to calculate $\% \mathrm{~A}_{\mathrm{bi}}$. This is a percentage 
of the picture that is black, not actual pixel area. Next $A_{g}$ and $A_{b g}$ are calculated with the following equations:

$$
\begin{gathered}
A_{g}=A_{i}-A_{v} \\
A_{b g}=\frac{A_{b i} * A_{i}}{A_{g}}
\end{gathered}
$$

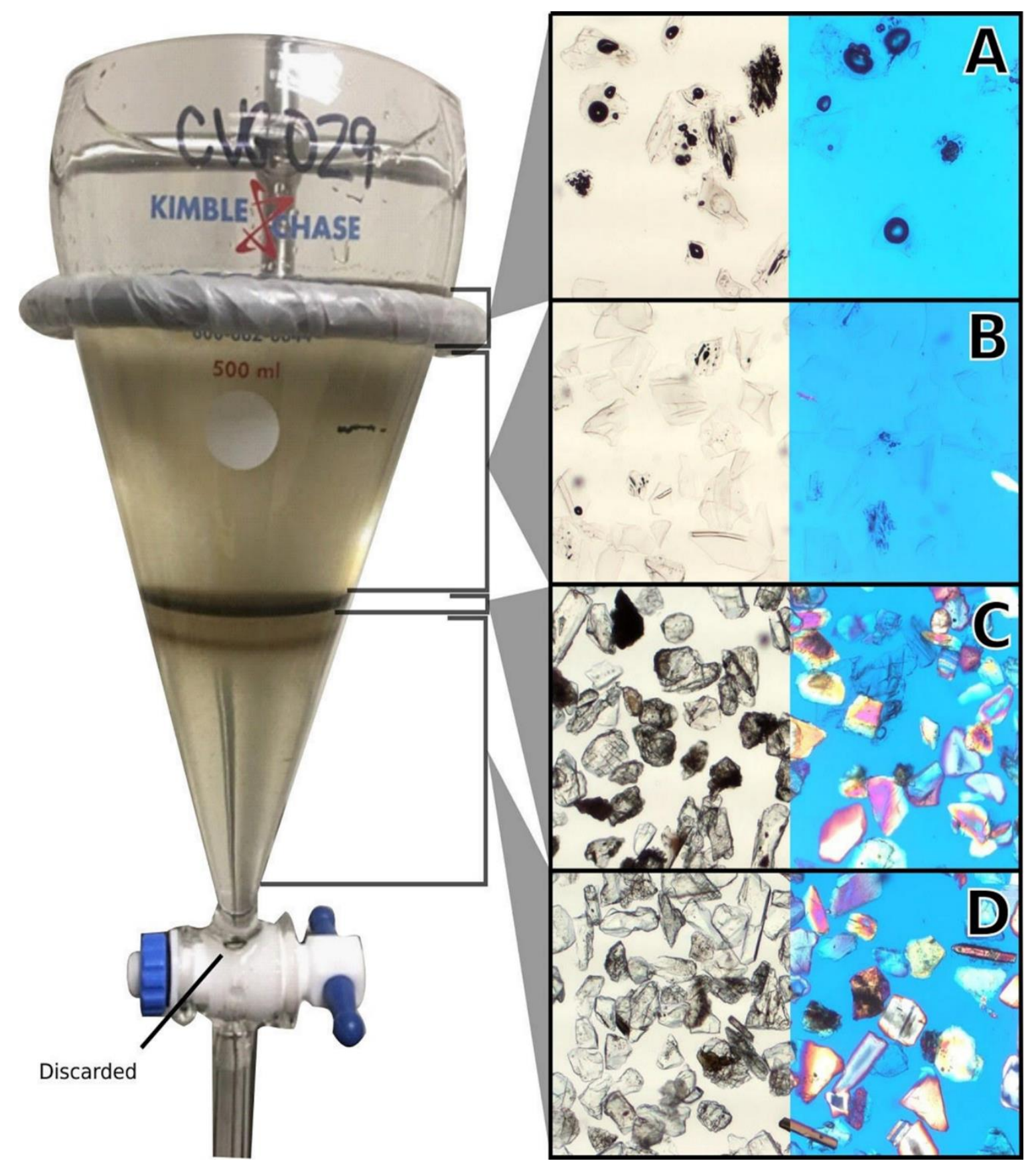

Figure 2: Image of LMT. A is the location where pumiceous shards are collected from, while B is where "pure" glass is collected. C and D contain contaminates that could not be removed with previous steps outlined in Cassel and Breecker (2017). The rainbow color is due to minerals in cross-polarized light, as light will pass through pristiene glass without any refraction. They are discarded. Images from Carlson (2018) 
Figure 3: Top: ImageJ color threshold processed image. The red was then used to calculate Abi. Bottom: Non-processed image from petrographic microscope. The bubble noted is an artifact from making the slide. It is cropped out before Abi is measured, thus not affecting apparent porosity $\left(\theta_{a}\right)$.
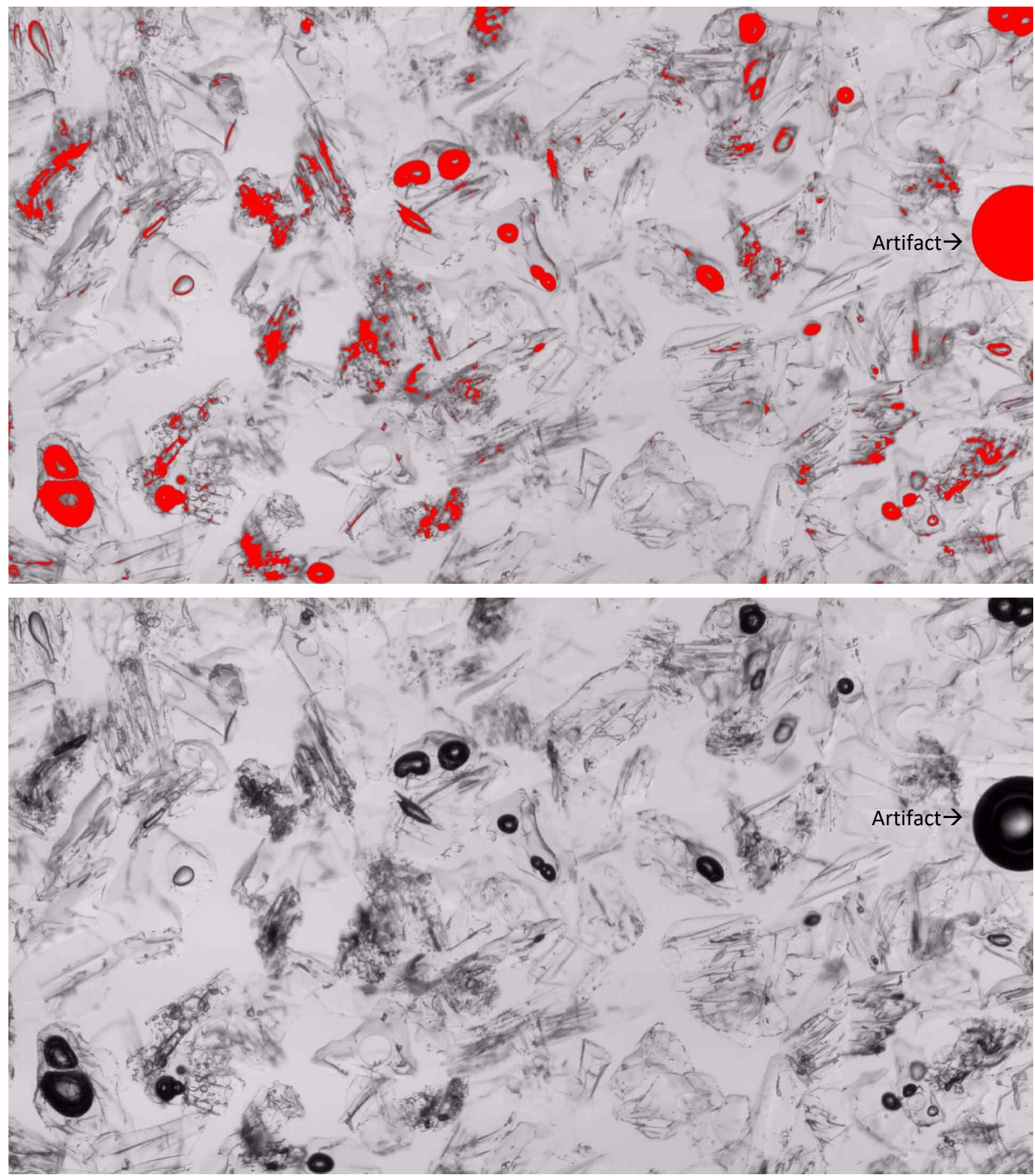
It should be noted that process of using ImageJ to estimate the apparent porosity is not as accurate as more established threedimensional methods (e.g. Add Refs here... do a quick Google Scholar search). ImageJ could not provide the level of detail needed to obtain a more accurate measurement without spending an inordinate amount of time differentiating 2 million pixels. In my analysis, this error would tend to increase $\theta_{\mathrm{a}}$ calculations. Image 4 (appendix) is different in color and glass density compared to the other samples due to limited sample size. Also, some error is introduced into the $\theta_{\mathrm{a}}$ calculation because of image differences.

\section{Results}

\begin{tabular}{|c|c|c|c|c|c|c|}
\hline Sample ID & Pumiceous & $\delta D$ & סD Range & $\%$ wt. water & $\%$ wt. water Range & Phi (a) \\
\hline M2-CVG027_a & yes & -148.6 & -1.2 & 4.13 & $0.10 \%$ & 5.6 \\
\hline M2-CVG027_b & no & -151.8 & 1.6 & 3.95 & $-0.04 \%$ & 0.1 \\
\hline M2-CVG029_a & yes & -152.9 & 2.2 & 3.395 & $-0.03 \%$ & 13.3 \\
\hline M2-CVG029_b & no & -151.3 & -1.1 & 3.185 & $0.19 \%$ & 0.3 \\
\hline M2-CVG034_a & yes & -163.1 & 1.9 & 6.495 & $0.07 \%$ & 4.9 \\
\hline M2-CVG034_b & no & -163.3 & 1.1 & 5.48 & $-0.16 \%$ & 1.7 \\
\hline
\end{tabular}

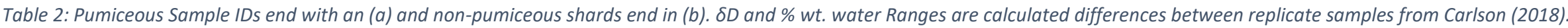




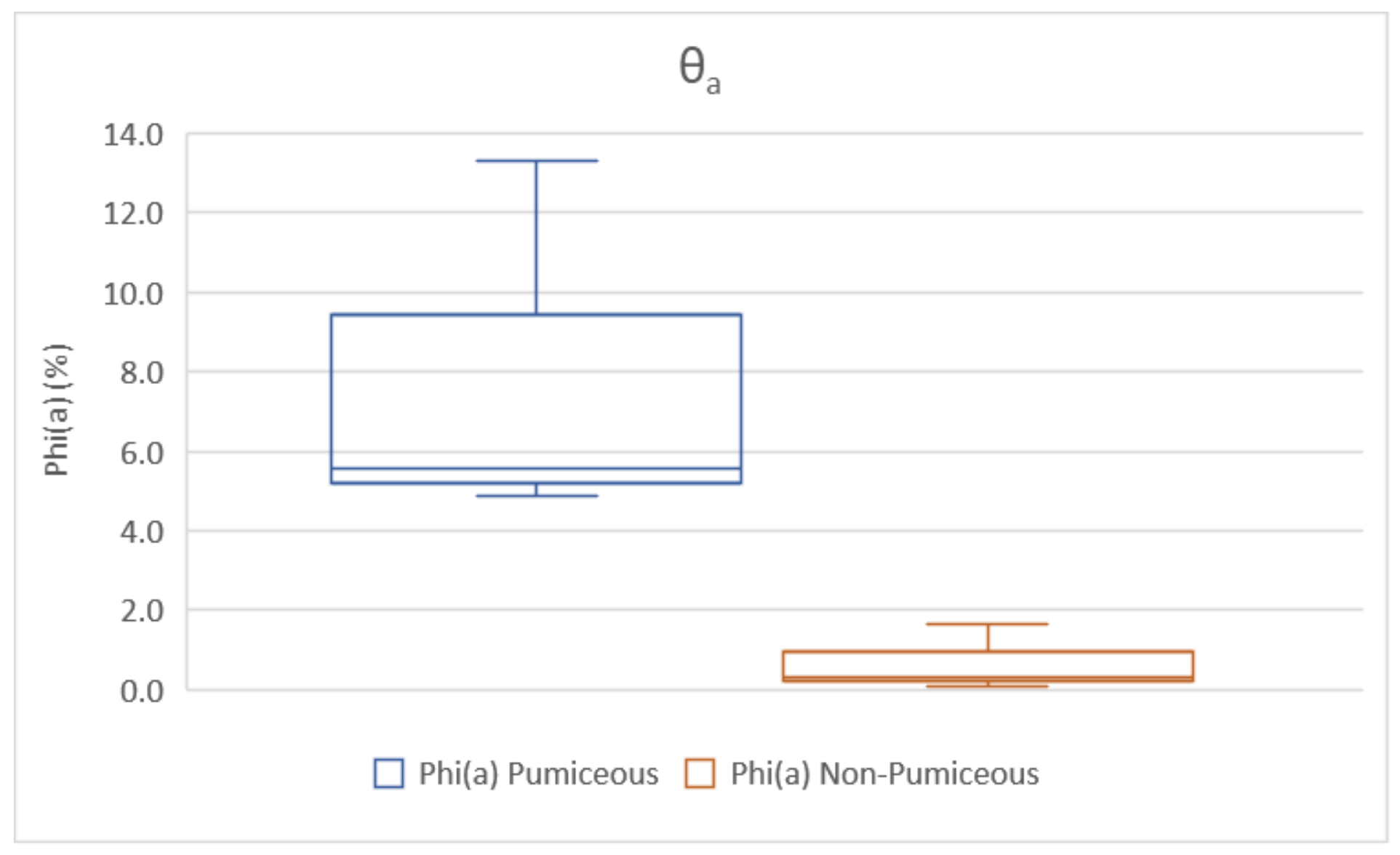

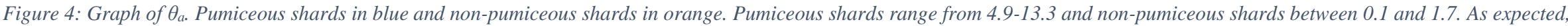
pumiceous shards have a significantly higher apparent porosity than non-pumiceous shards. 

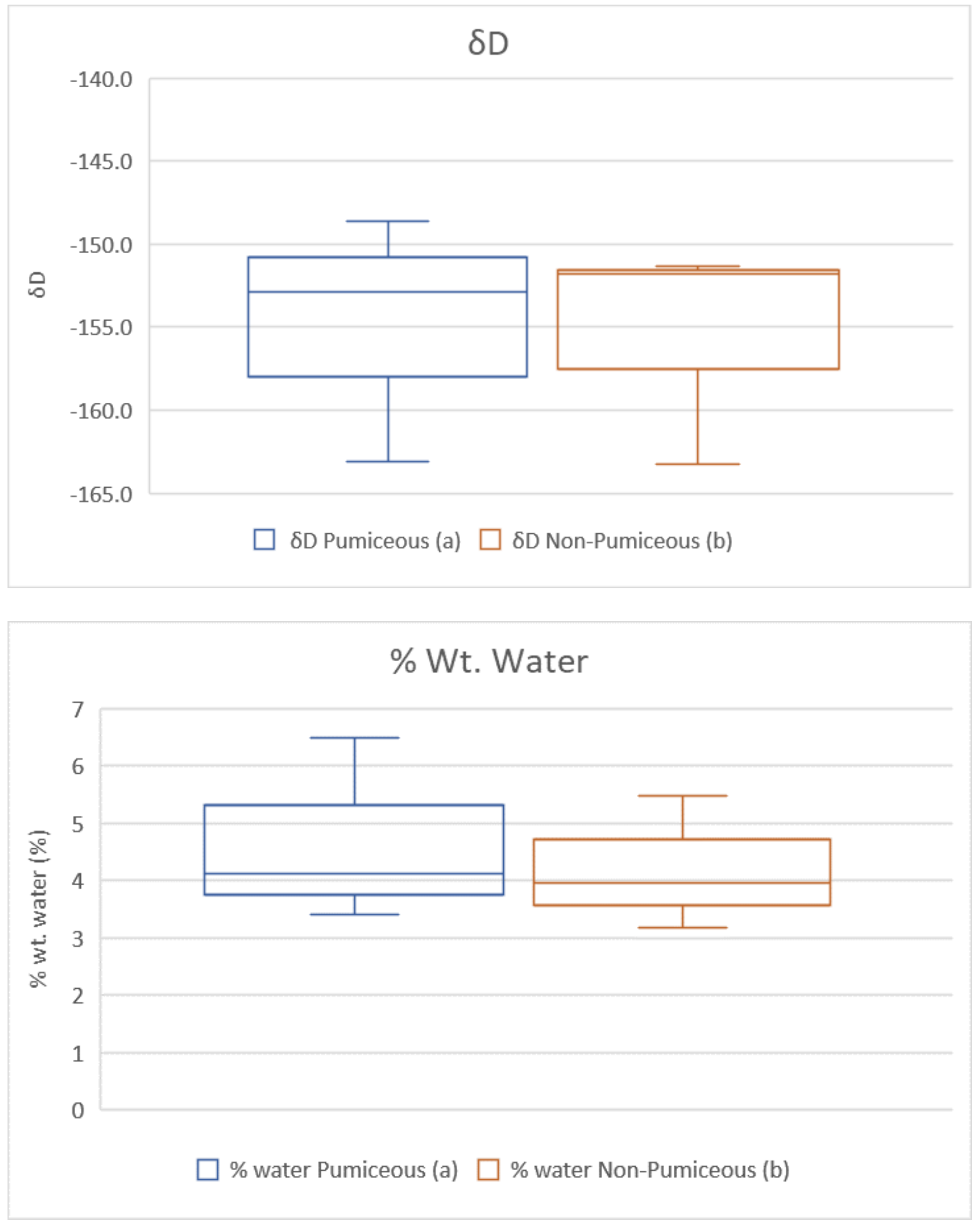

Figure 5: $\delta D$ and wt \% water graphs. Blue is pumiceous and orange non-pumiceous. Differences in wt. \% water and dD are not significant between pumiceous and non-pumiceous samples. 
As expected, pumiceous shards have a higher apparent porosity $\left(\theta_{\mathrm{a}}\right)$ than non-pumiceous shards. Apparent porosity $\left(\theta_{\mathrm{a}}\right)$ is highly variable between pumiceous and non-pumiceous samples. Pumiceous samples have a range of $8.4 \%$ while non-pumiceous samples have a range of only $1.6 \%$. The non-pumiceous shards all have a $\theta_{\mathrm{a}}$ less than $2 \%$ while pumiceous shards were between just under $5 \%$ to just over $13 \%$.

By contrast, wt. $\%$ water and $\delta \mathrm{D}$ do not differ significantly between pumiceous and nonpumiceous samples. Pumiceous samples contain between 3 and 7 wt. \% water and nonpumiceous between 3 and $6 \mathrm{wt}$. \% water. The largest wt. \% water difference between pumiceous and non-pumiceous shards is 1\% between samples M2-CVG034 (a) and (b) (Table 2). Among all samples, $\delta \mathrm{D}$ varies between $-148.6 \%$ and $163.3 \%$, but the difference between pumiceous and non-pumiceous of the same outcrop differ by just over 3.2\% in samples M2-CVG027 (a) and (b) (Table 2). To confirm the lack of relationship between either $\delta \mathrm{D}$ or wt. $\%$ water and apparent porosity $\left(\theta_{\mathrm{a}}\right)$, scatter plots were created (not shown) and no correlation observed $\left(\mathrm{R}^{2}<0.02\right)$.

\section{Discussion}

When comparing $\theta_{\mathrm{a}}, \delta \mathrm{D}$, and $\%$ wt. water, no correlations are observed. Despite significant differences in $\theta_{\mathrm{a}}$ between a pumiceous and non-pumiceous samples reaching $13 \%$, no significant differences in either $\delta \mathrm{D}$ or $\% \mathrm{wt}$. water among samples from the same outcrop are observed. These results are contrary to my hypothesis, and suggest that pumiceous samples with relatively high porosity and variable wt. \% water can also be used for paleoenvironmental reconstruction using $\delta \mathrm{D}$ analysis.

As stated, the Cassel and Breecker (2017) method uses several steps to prepare samples for analysis, including $\mathrm{HCl}, \mathrm{HF}$, and LMT. During this process, especially during HF treatment, surface contaminates and bubbles are eroded away and the total surface area of individual shards decreases (Carlson, 2018). Previously, pumiceous samples were discarded as they may contain more "contaminants" due to their high surface area to volume ratio and a higher propensity for post-hydration alteration and corrosion. My pilot study suggests that during the sample preparation process, contamination even in highly susceptible pumiceous samples is effectively eliminated, leaving meteoric hydrated glass behind.

\section{Conclusions}

Paleoenvironemental interpretation based on volcanic glass $\mathrm{dD}$ values is hampered uncertainties related to a dearth of data across the Pacific Northwest and elsewhere. My results are important as researchers may be able to sample a wider range of volcanic glass textures for paleoenvironmental analysis, particularly where exposure of non-pumiceous, non-welded tuff samples are limited. The amount of usable sample after treatment is often minimal, also limiting the number of results in published studies (Carlson, 2018). Contrary to previous practice, my 
results suggest non-pumiceous samples may also be used in analysis, which will potentially add critical datapoints for paleoenvironmental interpretation in future studies.

Future research should confirm these findings using the porosity of volcanic glass samples in three dimensions by measuring porosity using more comprehensive methods (e.g. Add Refs here... do a quick Google Scholar search). More importantly, these results suggest pumiceous samples do faithfully record the $\mathrm{dD}$ value of meteoric water at the time of ash deposition. However, the number of samples is limited so conclusions are suggestive in nature. A follow-up study should be conducted that analyzes a larger sample population to confirm my results and interpretations. 


\section{References}

Bershaw, J., Garzione, C.N., Higgins, P., MacFadden, B.J., Anaya, F., and Alvarenga, H., 2010, Spatial-temporal changes in Andean plateau climate and elevation from stable isotopes of mammal teeth: Earth and Planetary Science Letters, v. 289, p. 530-538, doi: 10.1016/j.epsl.2009.11.047.

Bestland, E.A., Forbes, M.S., Krull, E.S., Retallack, G.J., and Fremd, T., 2008, Stratigraphy, paleopedology, and geochemistry of the middle Miocene Mascall Formation (type area, central Oregon, USA): PaleoBios, v. 28, p. 41-61.

Canavan, R.R., Carrapa, B., Clementz, M.T., Quade, J., DeCelles, P.G., Schoenbohm, L.M., 2014. Early Cenozoic uplift of the Puna Plateau, Central Andes, based on stable isotope paleoaltimetry of hydrated volcanic glass. Geology 42, 447-450.

Carlson, T. (2018). Volcanic Glass as a Paleoenvironmental Proxy: Comparing Preparation Methods on Ashes from the Lee of the Cascade Range in Oregon, USA. (Master Thesis)

Cassel, E. J., \& Breecker, D. O. (2017). Long-term stability of hydrogen isotope ratios in hydrated volcanic glass. Geochimica et Cosmochimica Acta, 200, 67-86. doi:10.1016/j.gca.2016.12.001

Cassel, E.J., Graham, S.A., Chamberlain, C.P., 2009. Cenozoic tectonic and topographic evolution of the northern Sierra Nevada, California, through stable isotope paleoaltimetry in volcanic glass. Geology 37, 547-550.

Cerling, T. E., Brown, F. H., \& Bowman, J. R. (1985). Low-temperature alteration of volcanic glass: Hydration, Na, K, $18 \mathrm{O}$ and Ar mobility. Chemical Geology: Isotope Geoscience section,52(3-4), 281-293. doi:10.1016/0168-9622(85)90040-5

Cyr, A.J., Currie, B.S., Rowley, D.B., 2005. Geochemical evaluation of Fenghuoshan Group lacustrine carbonates, north-central Tibet: Implications for the paleoaltimetry of the Eocene Tibetan Plateau. The Journal of Geology 113, 517-533.

Dansgaard, W., 1964. Stable isotopes in precipitation. Tellus 16, 436-468.

Fan, M., Constenius, K.N., Dettman, D.L., 2017. Prolonged high relief in the northern Cordilleran orogenic front during middle and late Eocene extension based on stable isotope paleoaltimetry. Earth and Planetary Science Letters 457, 376-384.

Fiebelkorn, R.B., Walker, G.W., Macleod, N.S., Mckee, E.H., and Smith, J.G., 1982, Index to KAr Age Determinations for the State of Oregon.:

Fisher, R. V, and Schmincke, H.-U., 1984, Pyroclastic Rocks:

Friedman, I., Gleason, J., Warden, A., 2013. Ancient Climate from Deuterium Content of Water in Volcanic Glass. 309-319.

Giachetti, T., Gonnermann, H. M., Gardner, J. E., Shea, T., \& Gouldstone, A. (2015).

Discriminating secondary from magmatic water in rhyolitic matrix-glass of volcanic pyroclasts using thermogravimetric analysis. Geochimica et Cosmochimica Acta,148, 457-476. doi:10.1016/j.gca.2014.10.017

Grunder, A. L., Laporte, D., \& Druitt, T. H. (2005). Experimental and textural investigation of welding: effects of compaction, sintering, and vapor-phase crystallization in the rhyolitic 
Rattlesnake Tuff. Journal of Volcanology and Geothermal Research,142(1-2), 89-104. doi:10.1016/j.jvolgeores.2004.10.018

Nolan, G. S., \& Bindeman, I. N. (2013). Experimental investigation of rates and mechanisms of isotope exchange $(\mathrm{O}, \mathrm{H})$ between volcanic ash and isotopically-labeled water. Geochimica et Cosmochimica Acta,111, 5-27. doi:10.1016/j.gca.2013.01.020

Parruzot, B., Jollivet, P., Rébiscoul, D., \& Gin, S. (2015). Long-term alteration of basaltic glass: Mechanisms and rates. Geochimica et Cosmochimica Acta, 154, 28-48. doi:10.1016/j.gca.2014.12.011

Peterson, N. V, and Groh, E.A., 1970, Geologic tour of Cove Palisades State Park near Madras, Oregon: Oregon Department of Geology and Mineral Industries, v. 32, p. 141-168.

Pitcher, B.W., Kent, A.J.R., Grunder, A.L., and Duncan, R.A., 2017, Frequency and volumes of ignimbrite eruptions following the Late Neogene initiation of the Central Oregon High Cascades: Journal of Volcanology and Geothermal Research, v. 339, p. 1-22, doi: 10.1016/j.jvolgeores.2017.04.019.

Quade, J., Breecker, D.O., Daëron, M., Eiler, J., 2011. The paleoaltimetry of Tibet: An isotopic perspective. American Journal of Science 311, 77-115.

Rohrmann, A., Sachse, D., Mulch, A., Pingel, H., Tofelde, S., Alonso, R.N., Strecker, M.R., 2016. Miocene orographic uplift forces rapid hydrological change in the southern central Andes. Sci Rep 6, 35678.

Rowley, D.B., Garzione, C.N., 2007. Stable Isotope-Based Paleoaltimetry. Annual Review of Earth and Planetary Sciences 35, 463-508.

Rozanski, K., Araguás-Araguás, L., and Gonfiantini, R., 1993, Isotopic Patterns in 148 Modern Global Precipitation: Climate Change in COntinental Isotopic Records, v. 78, p. 1-36, doi: 10.1029/GM078p0001.

Saylor, J.E., Horton, B.K., 2014. Nonuniform surface uplift of the Andean plateau revealed by deuterium isotopes in Miocene volcanic glass from southern Peru. Earth and Planetary Science Letters 387, 120-131.

Seligman, A.N., Bindeman, I.N., Watkins, J.M., and Ross, A.M., 2016, Water in volcanic glass: From volcanic degassing to secondary hydration: Geochimica et Cosmochimica Acta, v. 191, p. 216-238, doi: 10.1016/j.gca.2016.07.010.

Williams, H., \& McBirney, A. R. (1979). Volcanology: Howel Williams and Alexander R. McBirney ; illustrated by Christine McBirney. San Francisco: CA, Freeman, Cooper. 


\section{Appendix}

A: Initial, unprocessed glass images.

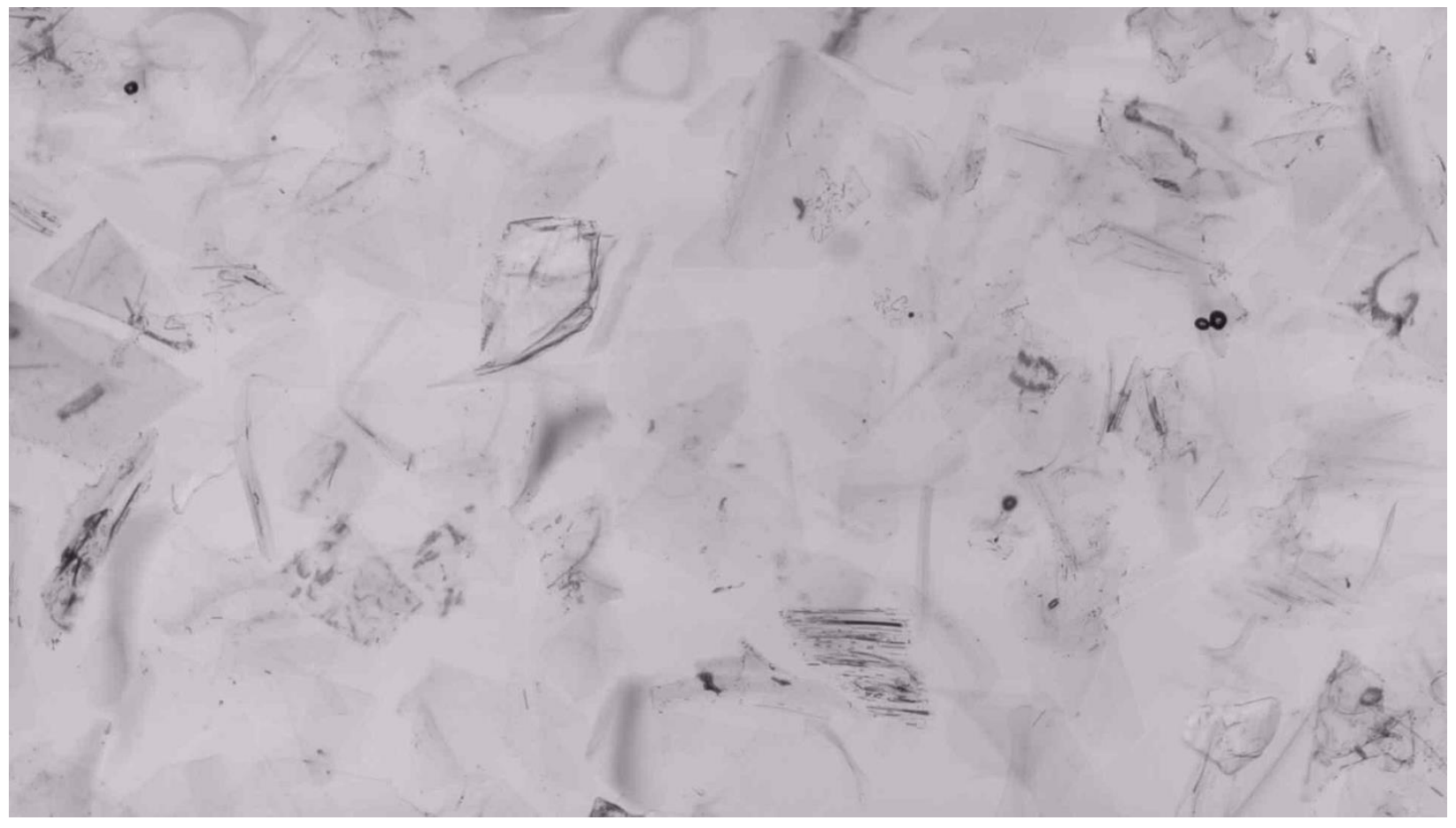

Image 1: Sample 27, pure

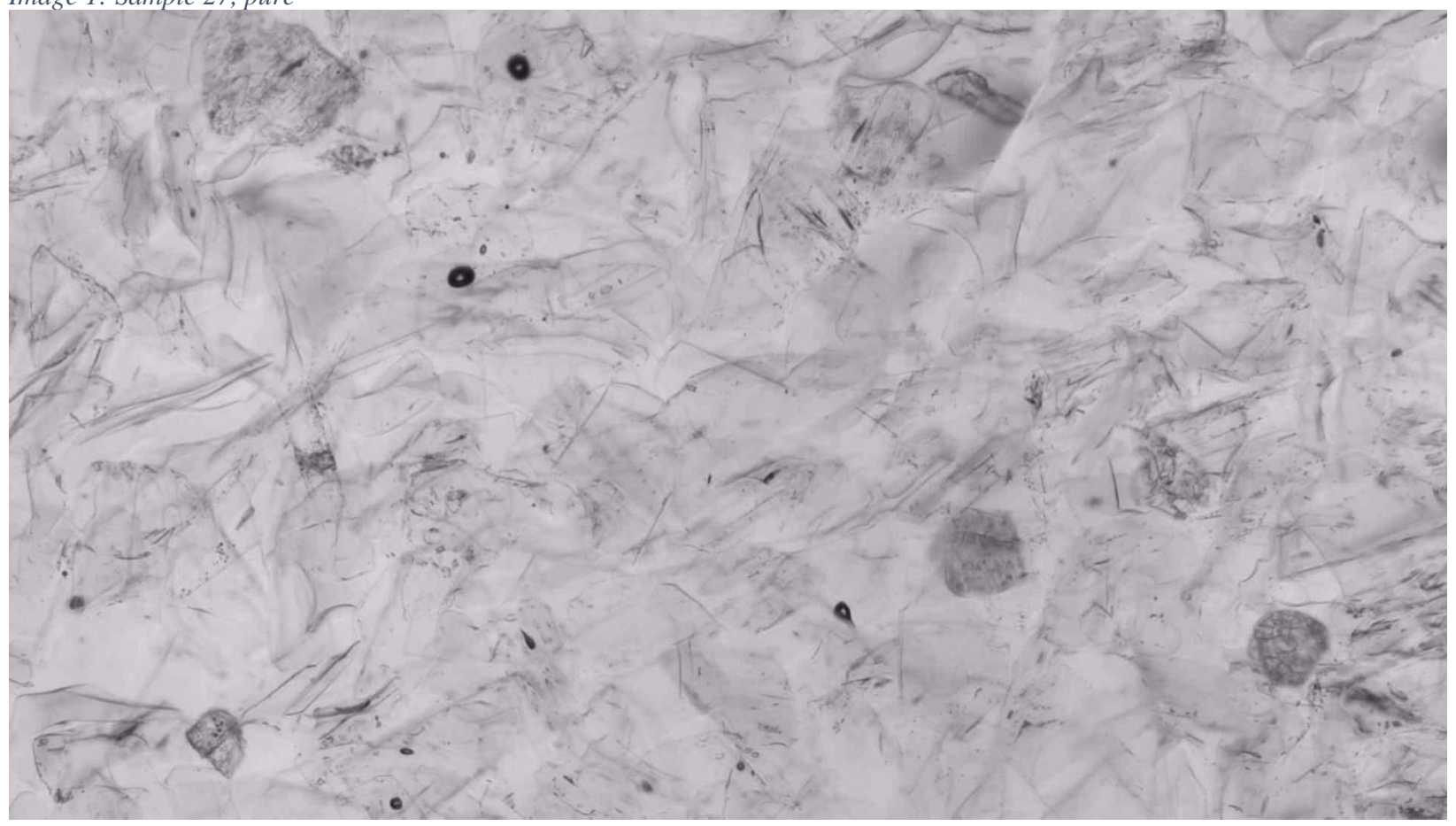

Image 2: Sample 29, pure 


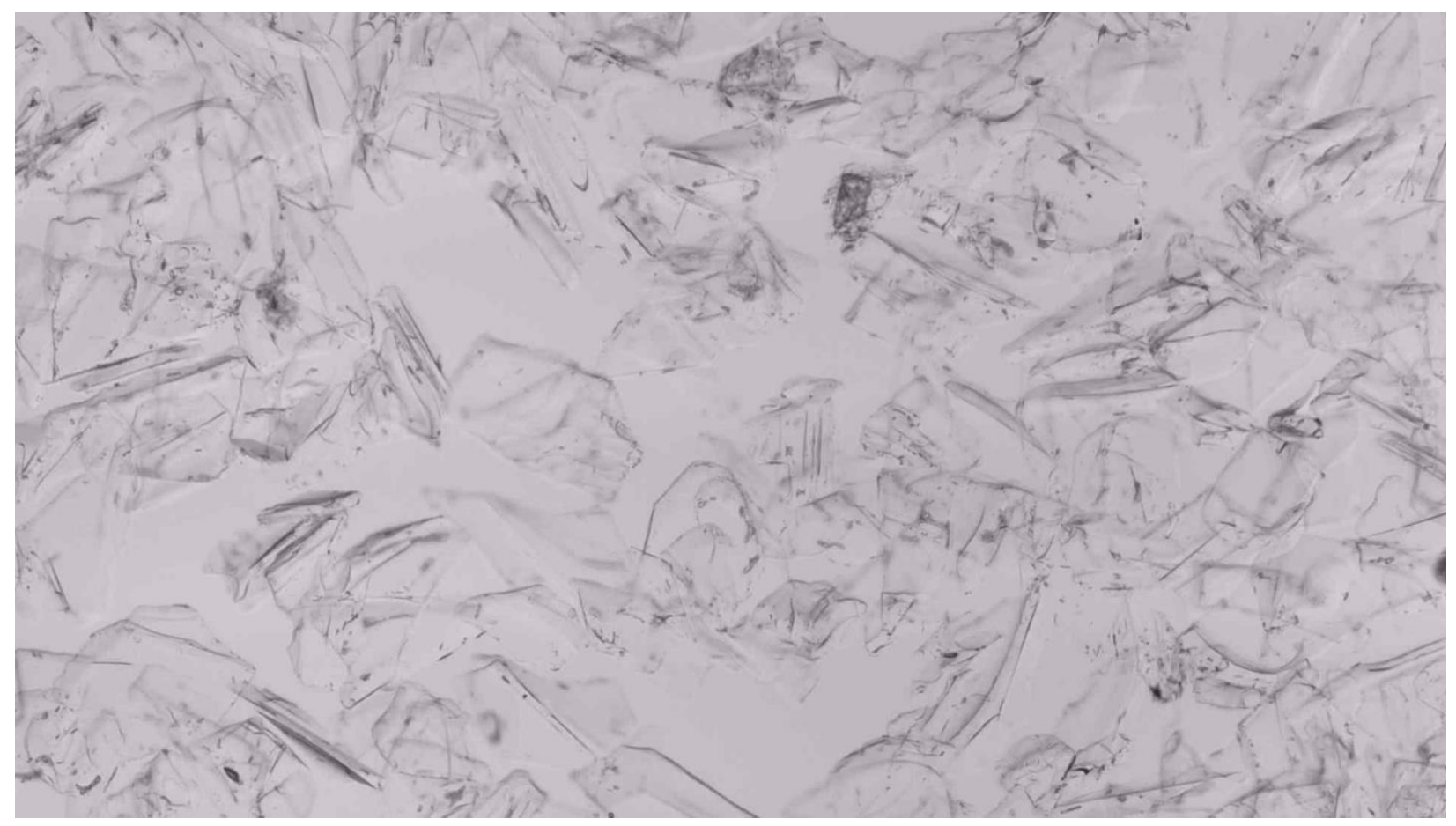

Image 3: Sample 34, pure

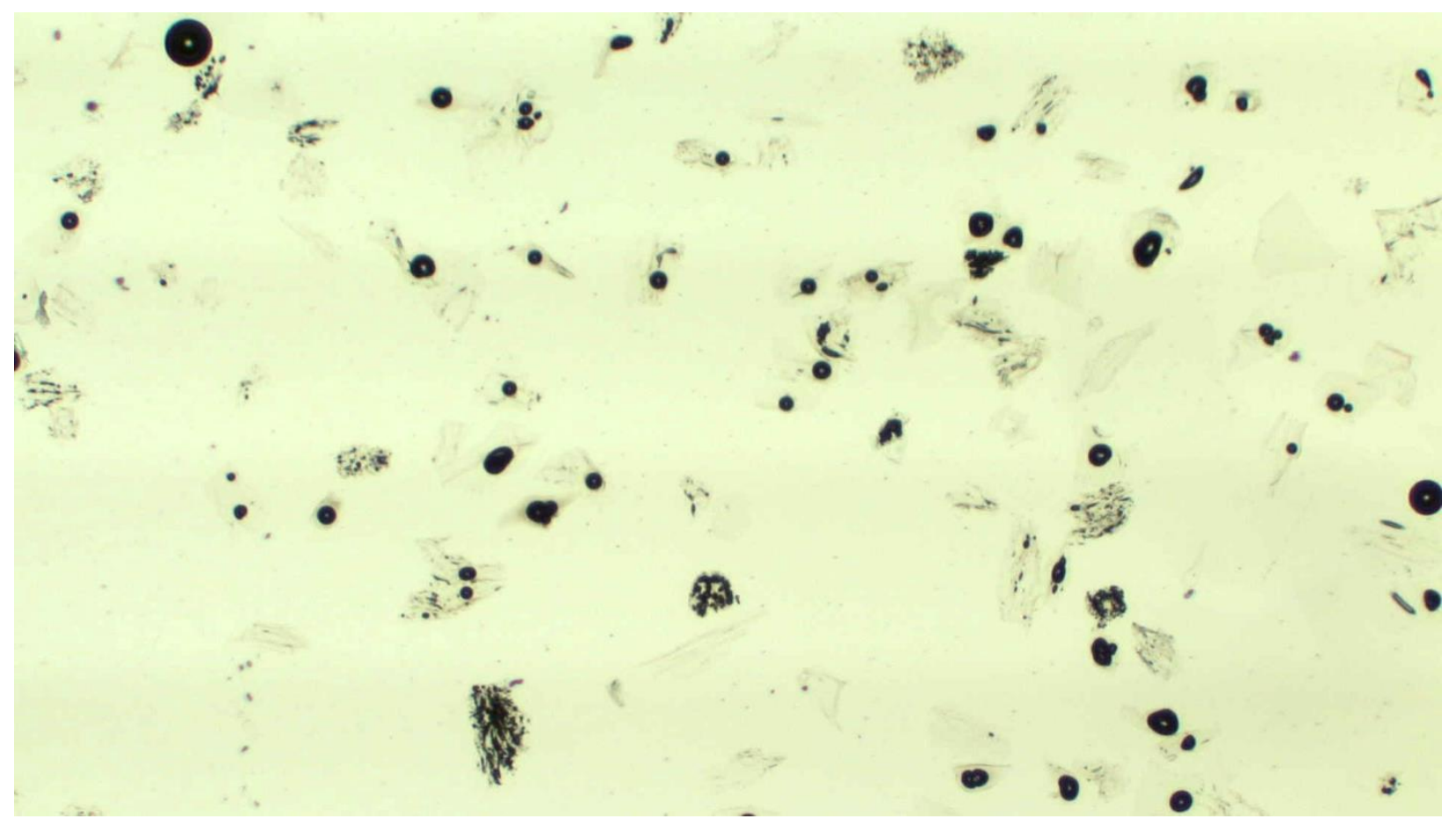

Image 4: Sample 27, pumiceous 


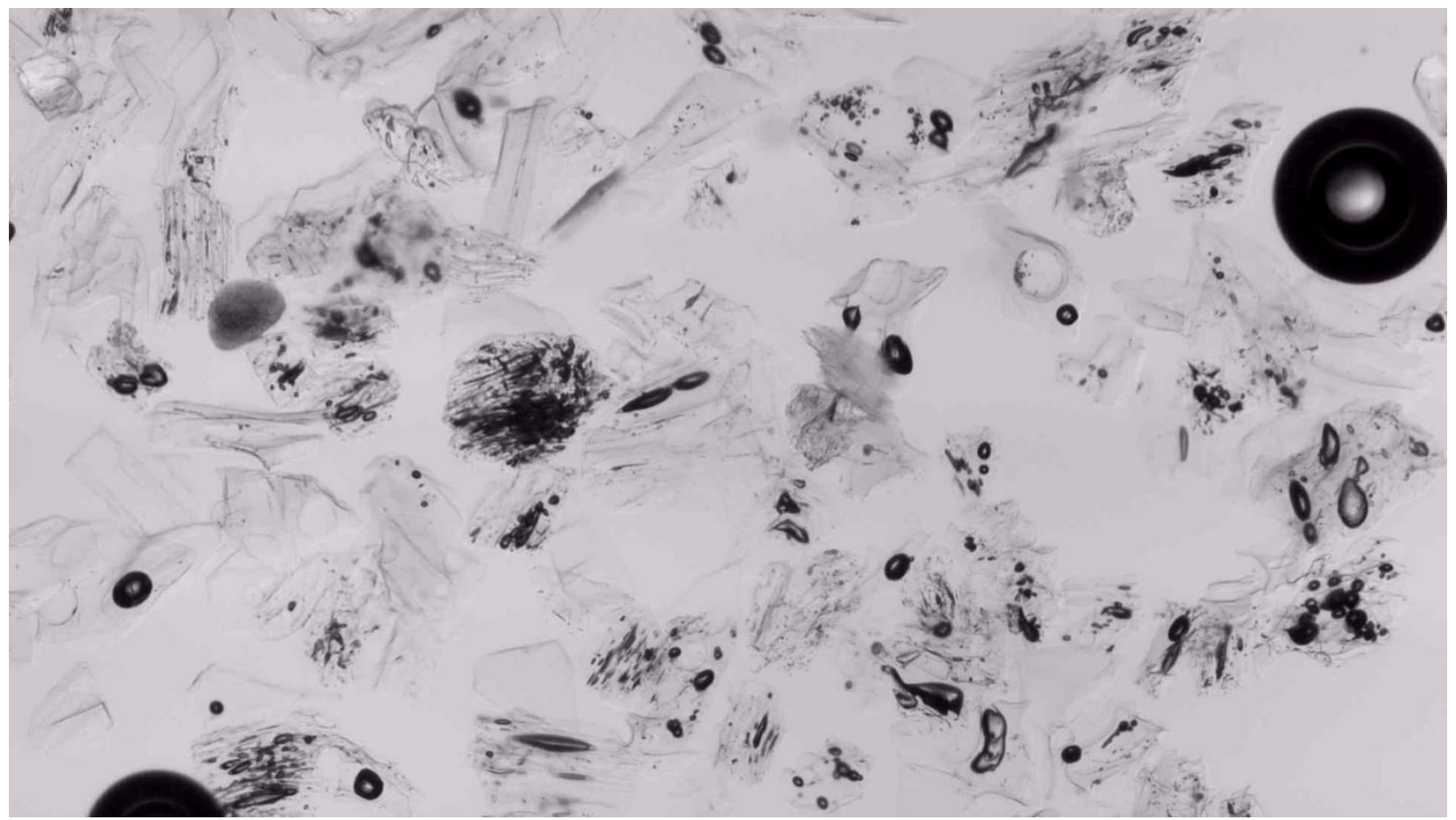

Image 5: Sample 29, pumiceous

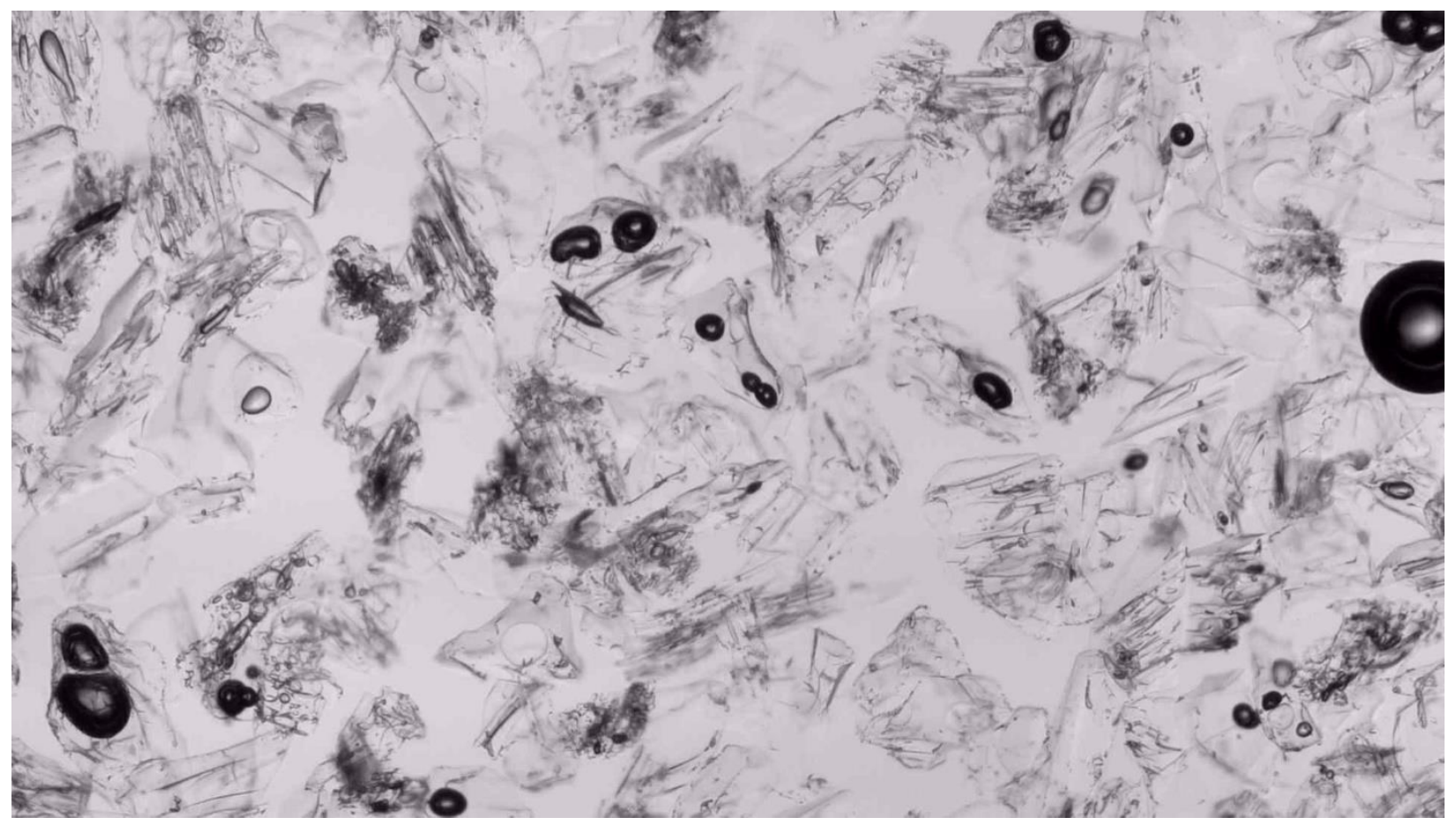

Image 6: Sample 34, pumiceous 
B: Processed Images for $\% A_{b}$

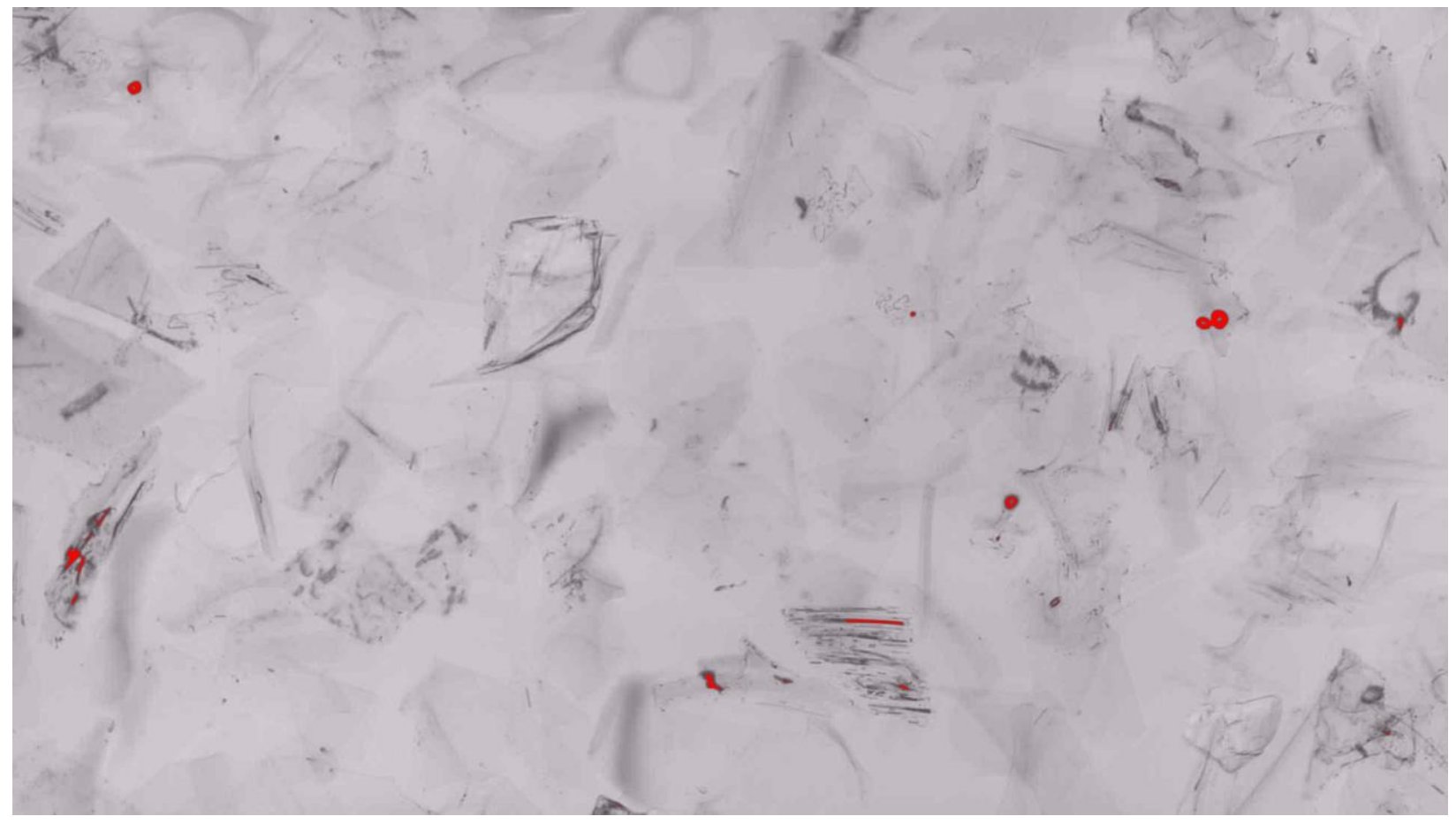

Image 7: Sample 27, pure, processed for $\% A_{b}$

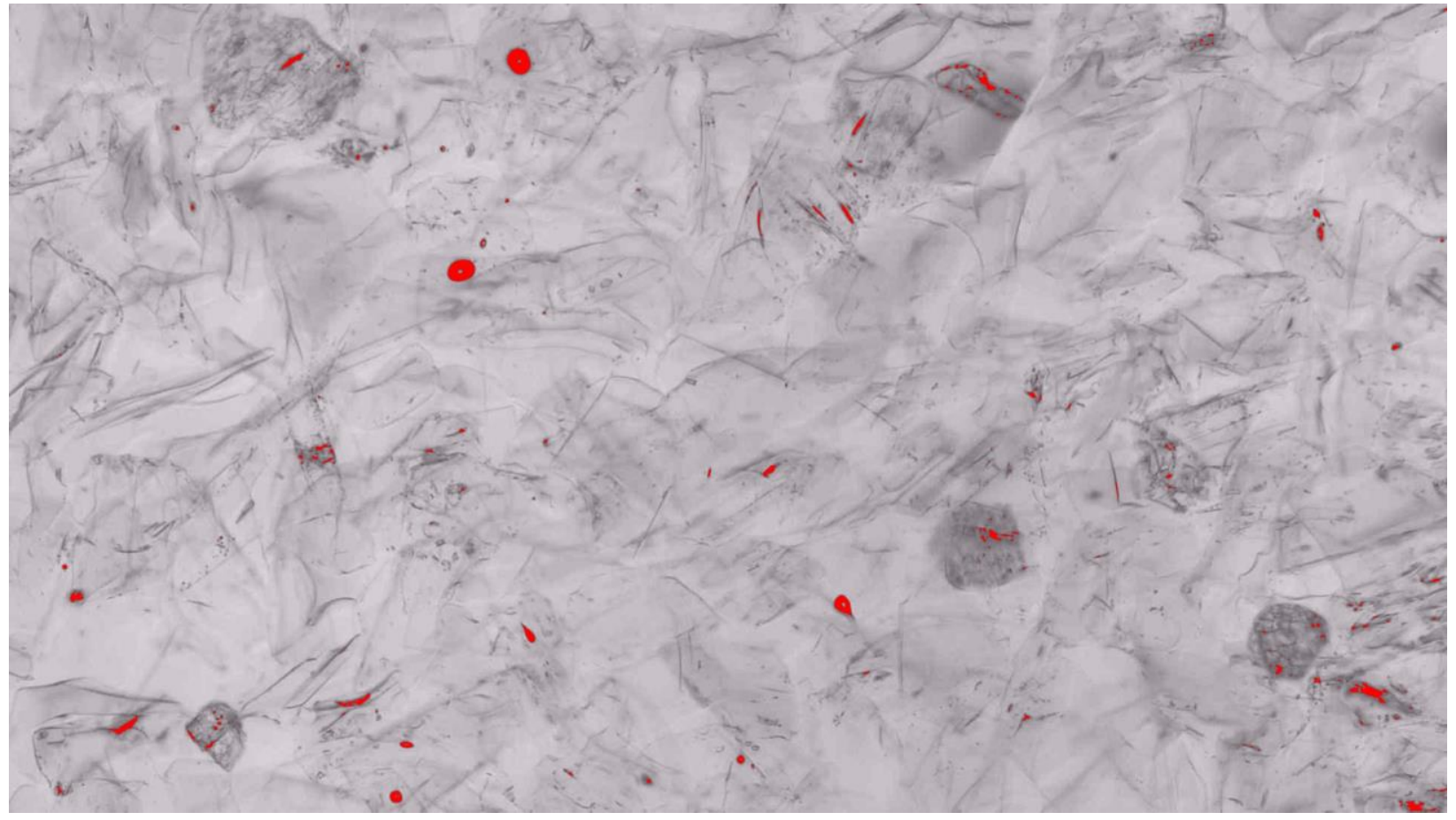

Image 8: Sample 29, pure, processed for $\% A_{b}$ 


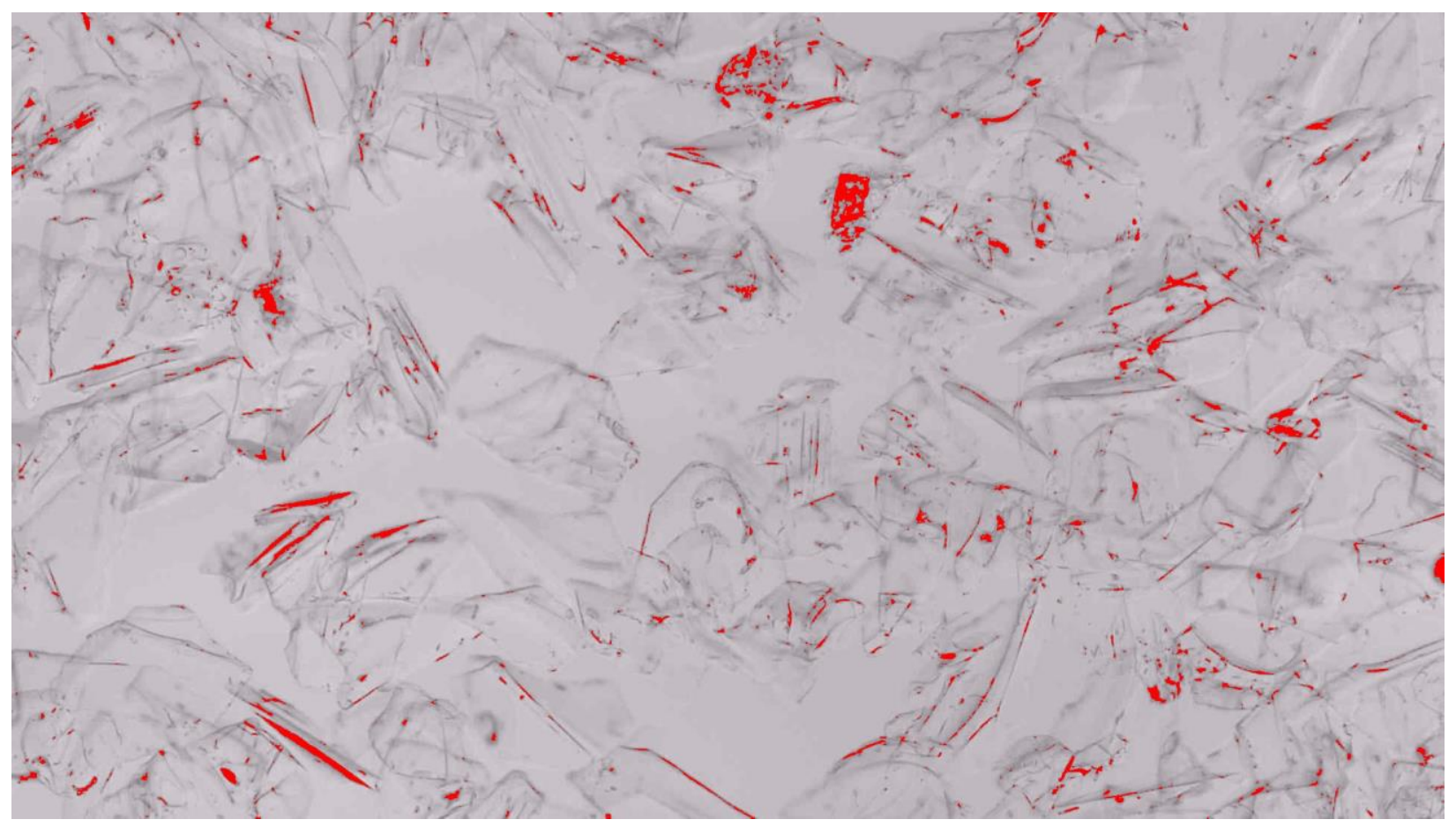

Image 9: Sample 34, pure, processed for $\% A_{b}$

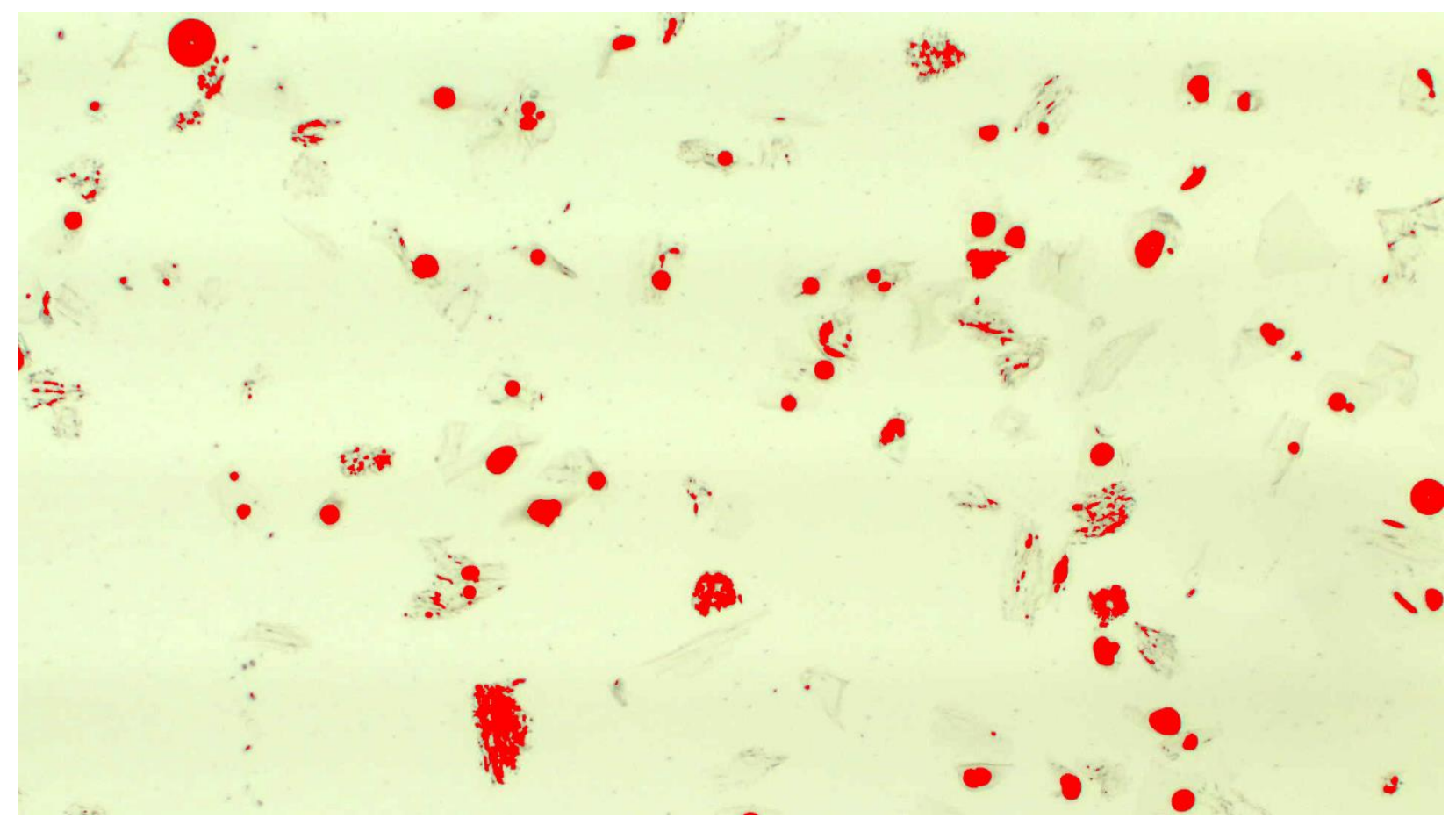

Image 10: Sample 27, pumiceous, processed for $\% A_{b}$ 


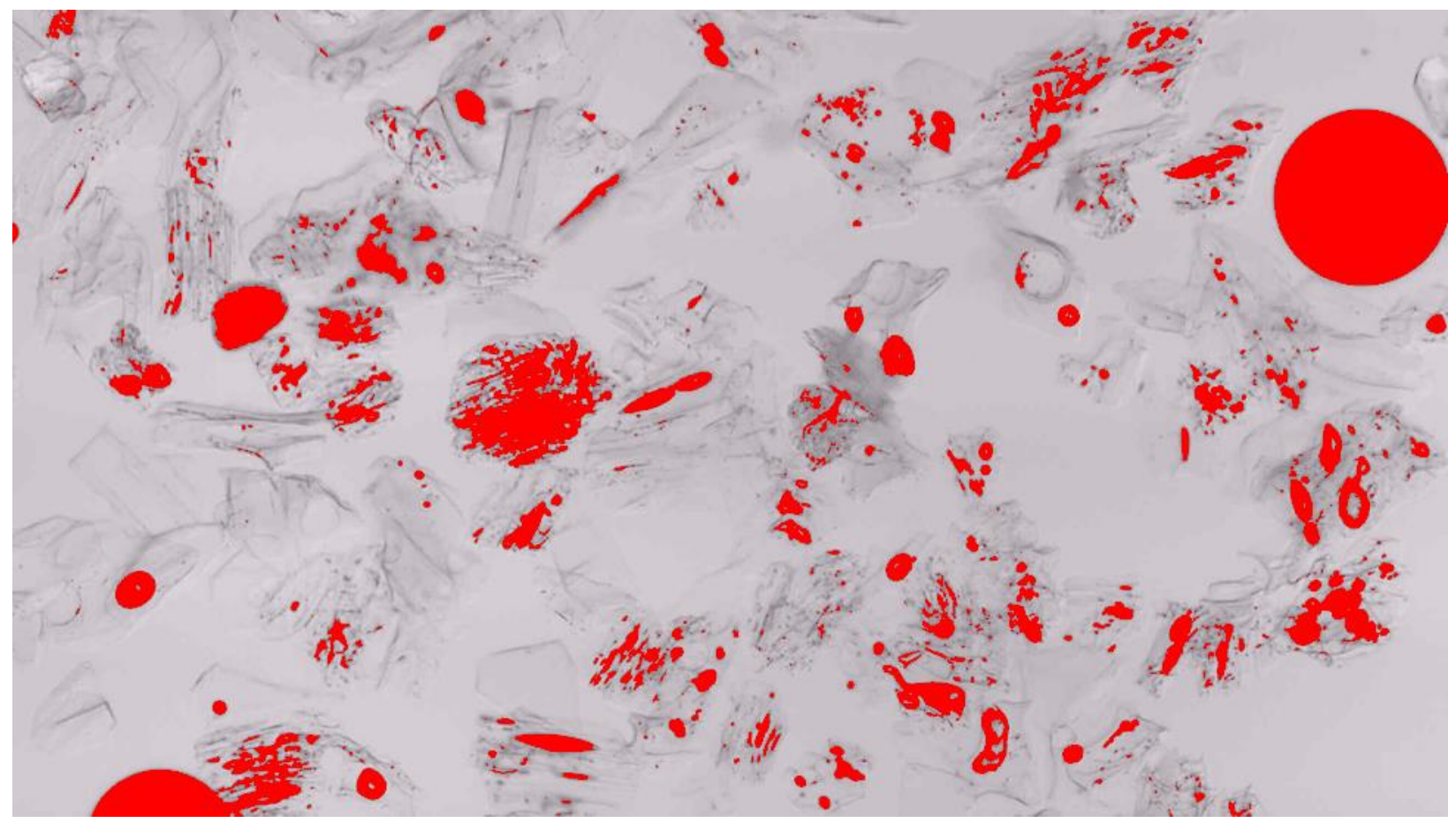

Image 11: Sample 29, pumiceous, processed for $\% A_{b}$

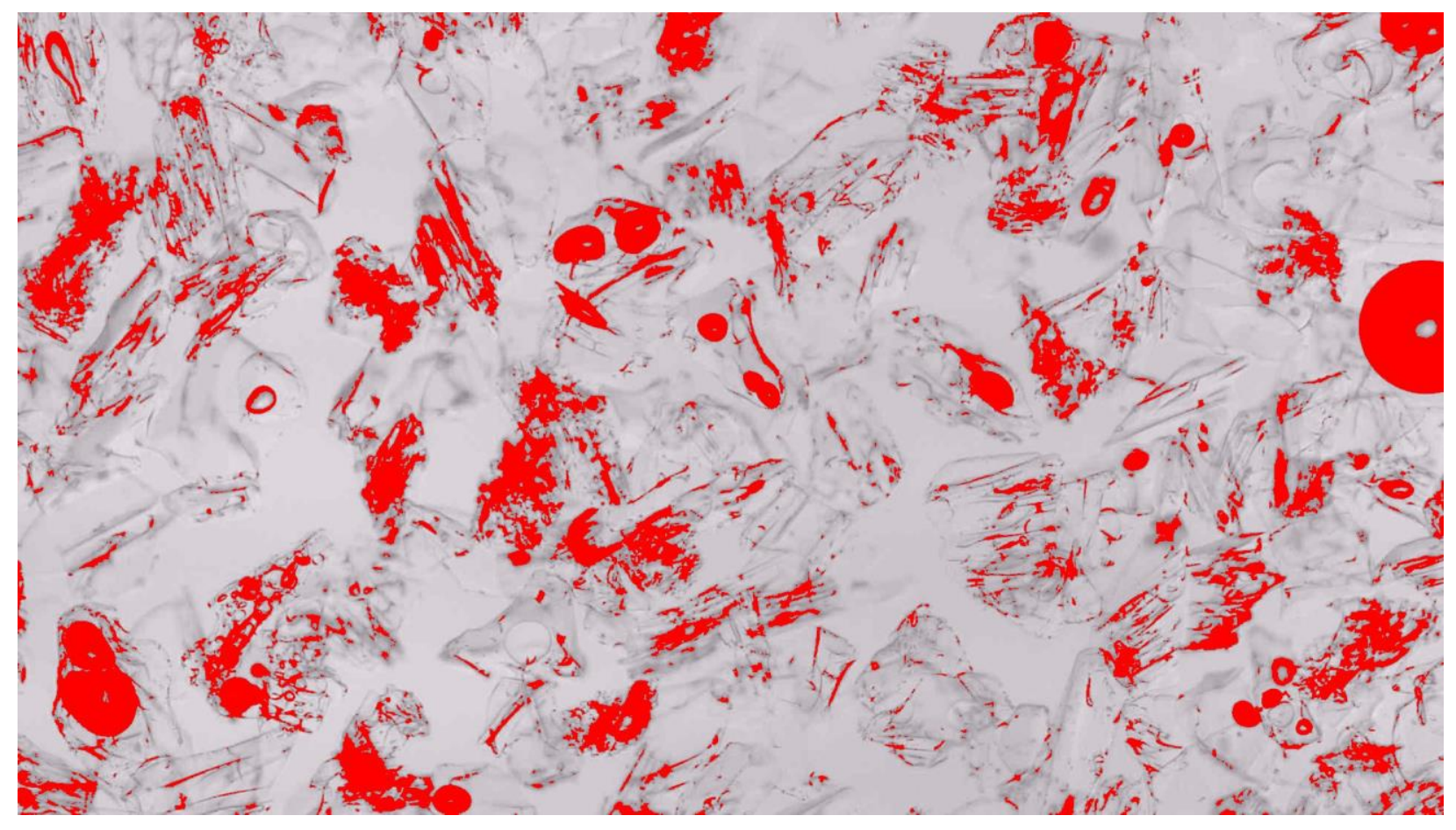

Image 12: Sample 34, pumiceous, processed for $\% A_{b}$ 


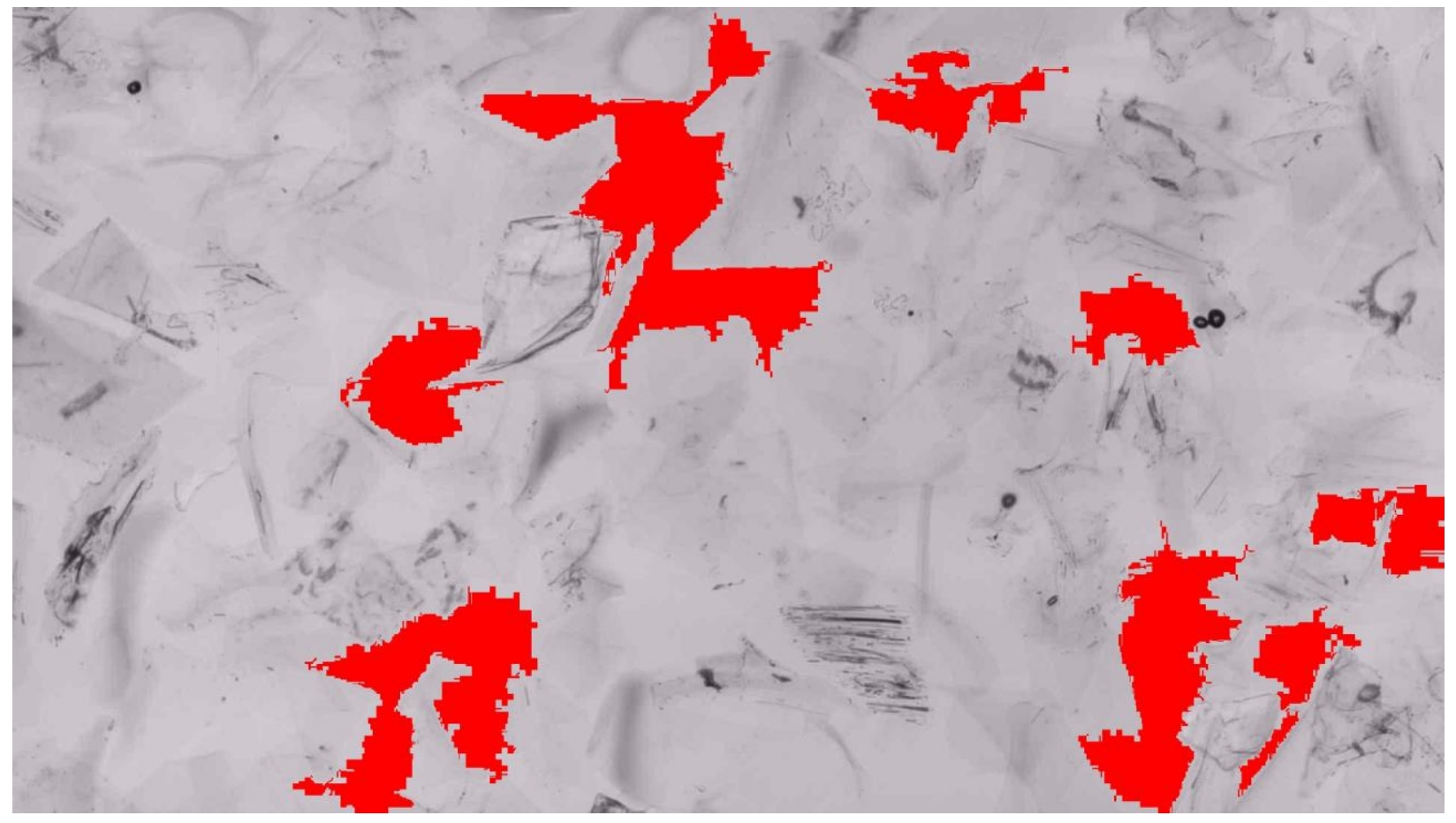

Image 13: Sample 27, non-pumiceous, Av

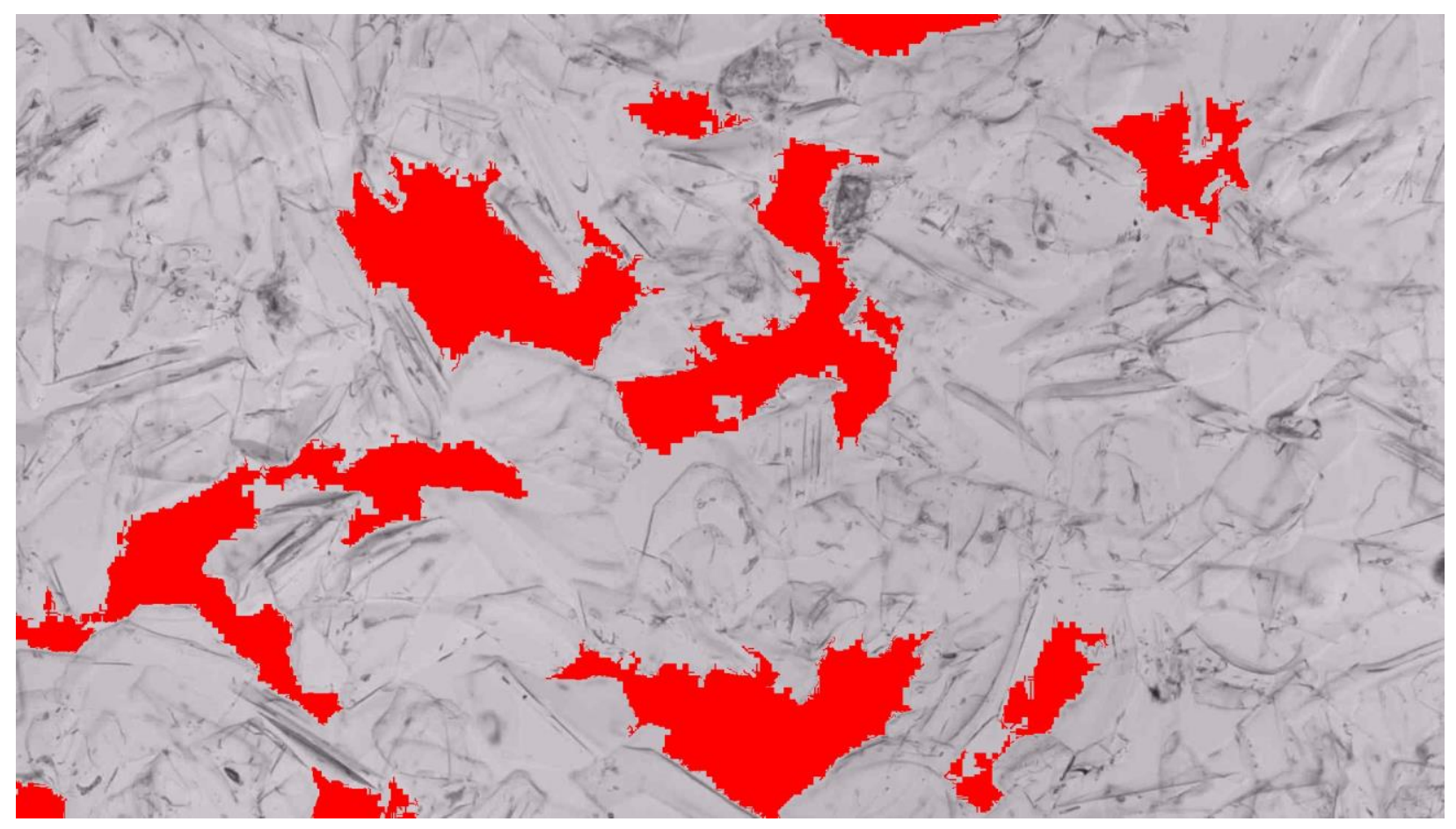

Image 4: Sample 34, non-pumiceous, Av 


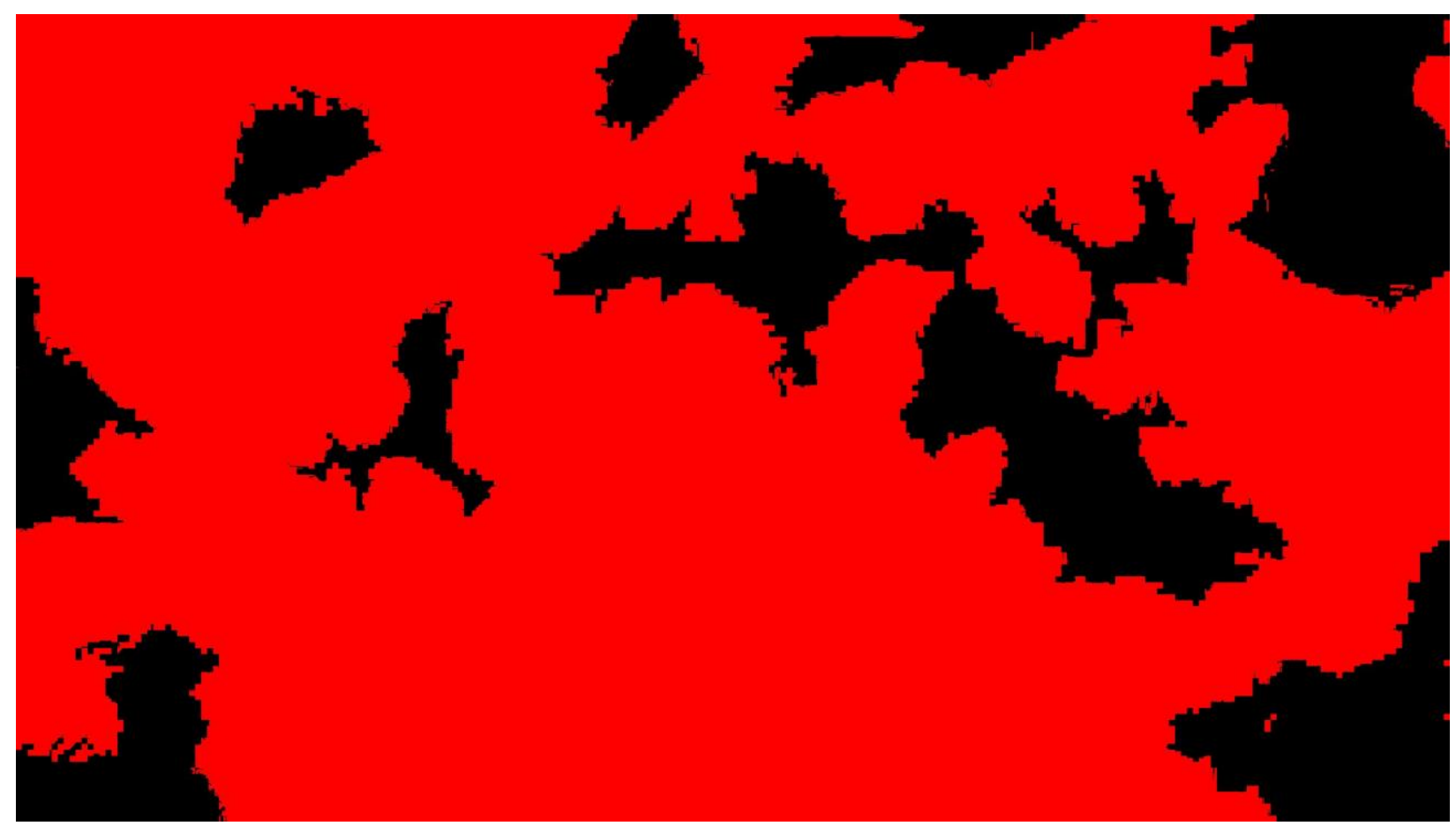

Image 15: Sample 29, pumiceous, Av

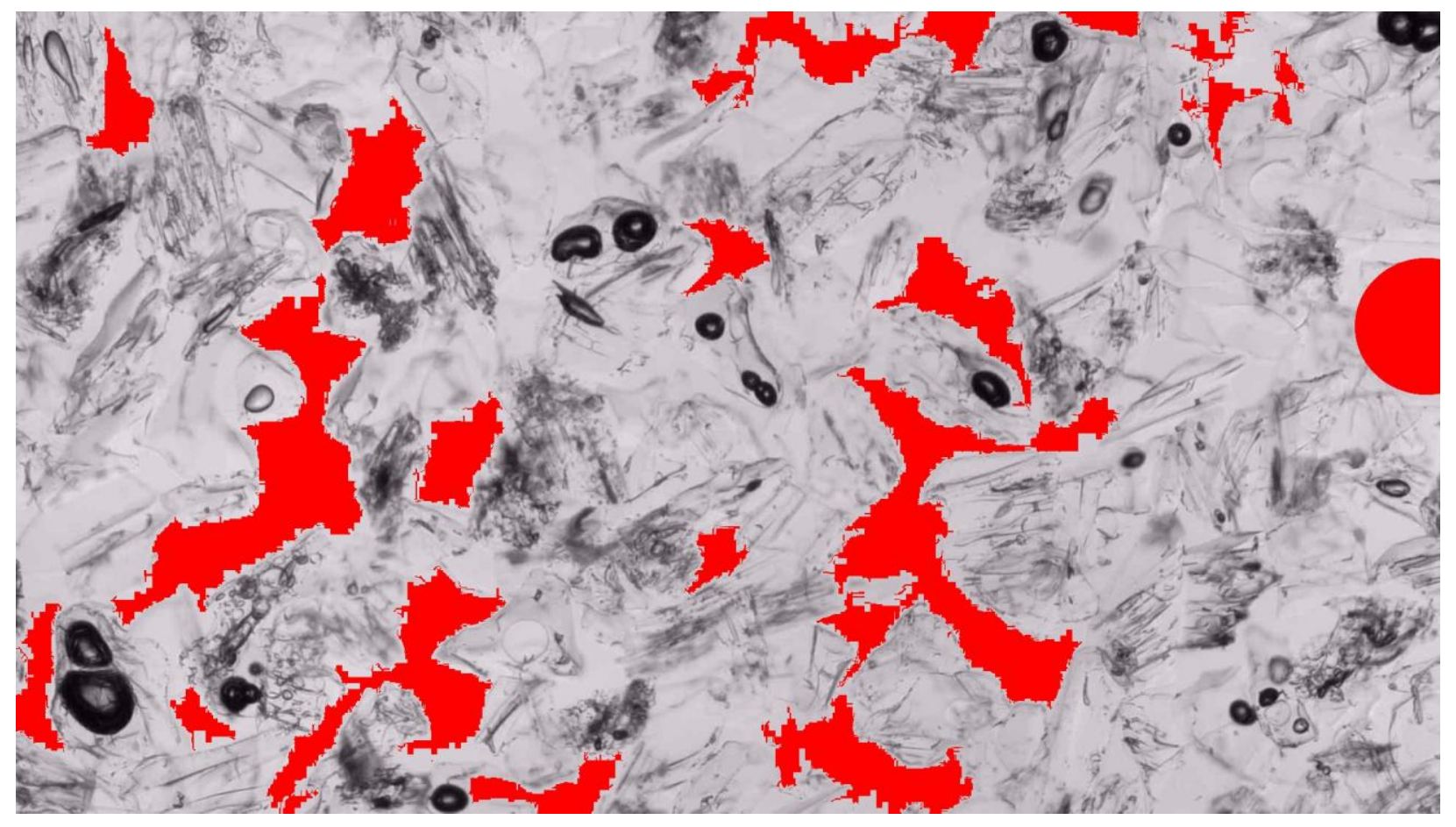

Image 16: Sample 34, pumiceous, Av 